\title{
Current limitations and future prospects of detection and biomonitoring of NIS in the Mediterranean Sea through environmental DNA
}

\author{
Francesco Zangaro ${ }^{1,2^{*}}$, Benedetta Saccomanno ${ }^{{ }^{*}}$, Eftychia Tzafesta', \\ Fabio Bozzeda ${ }^{1,2}$, Valeria Specchia', Maurizio Pinna, ${ }^{1,2}$
}

I Department of Biological and Environmental Sciences and Technologies, DiSTeBA, University of Salento, via Monteroni 165, 73100 Lecce, Italy 2 Research Centre for Fisheries and Aquaculture of Aquatina di Frigole, DiSTeBA, University of Salento, 73100 Lecce, Italy

Corresponding author: Maurizio Pinna (maurizio.pinna@unisalento.it)

Academic editor: Nicola Smith | Received 20 July 2021 | Accepted 20 November 2021 | Published 14 December 2021

Citation: Zangaro F, Saccomanno B, Tzafesta E, Bozzeda F, Specchia V, Pinna M (2021) Current limitations and future prospects of detection and biomonitoring of NIS in the Mediterranean Sea through environmental DNA. NeoBiota 70: 151-165. https://doi.org/10.3897/neobiota.70.71862

\begin{abstract}
The biodiversity of the Mediterranean Sea is currently threatened by the introduction of Non-Indigenous Species (NIS). Therefore, monitoring the distribution of NIS is of utmost importance to preserve the ecosystems. A promising approach for the identification of species and the assessment of biodiversity is the use of DNA barcoding, as well as DNA and eDNA metabarcoding. Currently, the main limitation in the use of genomic data for species identification is the incompleteness of the DNA barcode databases. In this research, we assessed the availability of DNA barcodes in the main reference libraries for the most updated inventory of 665 confirmed NIS in the Mediterranean Sea, with a special focus on the cytochrome oxidase I (COI) barcode and primers. The results of this study show that there are no barcodes for $33.18 \%$ of the species in question, and that $45.30 \%$ of the 382 species with COI barcode, have no primers publicly available. This highlights the importance of directing scientific efforts to fill the barcode gap of specific taxonomic groups in order to help in the effective application of the eDNA technique for investigating the occurrence and the distribution of NIS in the Mediterranean Sea.
\end{abstract}

\section{Keywords}

Biomonitoring, COI, DNA barcode, environmental DNA - eDNA, gap analysis, Mediterranean Sea, Non-Indigenous Species - NIS, reference libraries

* Those authors contributed equally to this work.

Copyright Francesco Zangaro et al. This is an open access article distributed under the terms of the Creative Commons Attribution License (CC BY 4.0), which permits unrestricted use, distribution, and reproduction in any medium, provided the original author and source are credited. 


\section{Introduction}

The Mediterranean Sea represents one of the most important biodiversity hotspots in the world (Myers et al. 2000; Coll et al. 2010; Lejeusne et al. 2010; Marrocco et al. 2019), accounting for more than 17,000 reported marine species (Coll et al. 2010). However, the number of Non-Indigenous Species (NIS) and their impact on native species is steadily increasing (Villèle and Verlaque 1995; Streftaris and Zenetos 2006; Marrocco et al. 2018; Bariche et al. 2020). Therefore, the Mediterranean Scientific Community highlights the importance of early warnings and monitoring the presence and distribution of NIS (Katsanevakis et al. 2016; Darling et al. 2017; Tsiamis et al. 2020). Nowadays, this is a key requirement for the conservation and management of ecosystems, as stated by the regulation (EU) No 1143/2014 of the European Parliament and of the Council of 22 October 2014 on the prevention and management of the introduction and spread of invasive alien species (Tiralongo et al. 2019).

Until now, the assessment of Mediterranean species diversity has been carried out through traditional methods based on sole morphological identification. These methods present several disadvantages, such as the difficulty in surveying large geographical areas and spotting and identifying the so-called "hard-to-detect species" (Tiralongo et al. 2020). Besides, they are mainly based on recognizable adult features, such as the shape of gonads or other particular body parts and, often, do not give any identification key for the larval forms or the early developmental stages (Ponti et al. 2009; Di Sabatino et al. 2014; Pinna et al. 2017). They also easily mislead the identification of individuals when their morphology is altered by stressful environmental conditions or by sampling and preservation techniques (Leese et al. 2016; Pawlowski et al. 2018; Tiralongo et al. 2020). In addition, traditional phenotypic-based methods require the expertise of taxonomists, especially when there is the need to identify a species never observed before in a certain area, including NIS (Leese et al. 2016; Pawlowski et al. 2018).

Consistent biological records can provide a better understanding of the distribution of marine species, their expansion range, and the arrival of new NIS in the Mediterranean basin (Mannino et al. 2019; Bariche et al. 2020). A promising approach for the identification of species and biomonitoring of ecosystems is the use of molecular tools such as DNA barcoding, metabarcoding and environmental DNA (Pawlowski et al. 2018; Specchia et al. 2020; Pinna et al. 2021; Tzafesta et al. 2021). DNA barcoding refers to a single species identification with the use of a short DNA fragment, while in the metabarcoding technique the DNA is extracted from a sample containing more than one organism/species, amplified and sequenced by Next Generation Sequencing (NGS) (Ji et al. 2013; Deiner et al. 2017). DNA metabarcoding allows the identification of species at low densities and the detection of taxa that traditional approaches generally fail to distinguish (Pawlowski et al. 2018; Zangaro et al. 2020). Another innovative technique for the identification of species at low concentration is the eDNA (Pawlowski et al. 2018), which is based on the extraction of DNA directly from environmental samples like water or sediment (Rees et al. 2014). This technique can efficiently be applied for assessing the presence and the distribution of NIS that are hard to detect. 
Also, it may result in a perfect tool for monitoring and preventing new NIS arrivals, for instance, by analysing the genetic content of ballast waters and monitoring it in water exchanges between different regions (Bariche et al. 2020; Tzafesta et al. 2021).

However, even the application of molecular techniques faces some challenges. The level of uncertainty linked to eDNA for marine environments depends generally on the persistence time of the DNA in marine systems (Collins et al. 2018), the high level of connection and movement due to the aquatic medium, and the incompleteness of the reference public libraries (Cagnacci et al. 2012; Weigand et al. 2019; Specchia et al. 2020). Once a DNA fragment has been sequenced, it needs to be blasted into reference libraries to identify the species it belongs to. Moreover, the success of the eDNA technique is also based on the efficiency of the primer sets on large numbers of taxa, a key requirement to correctly amplify the investigated gene in the environmental sample to identify as many species as possible (Elbrecht et al. 2017).

The main DNA barcode reference libraries are GenBank, by the National Centre for Biotechnology Information (NCBI), and BOLD (Barcode of Life Data) Systems (Ratnasingham et al. 2007; Leese et al. 2016; Macher et al. 2017). The information available in the reference libraries includes the species name, the nucleotide sequence of the target genes and, optionally, the PCR primer pairs used for the amplification of the gene of interest in the target organism (Ratnasingham et al. 2007; Macher et al. 2017).

The Consortium for the Barcode of Life (CBOL; www.barcoding.si.edu.com) and the International Nucleotide Sequence Database Collaborations (INSDC) designated the mitochondrial cytochrome oxidase subunit I (COI) as the main barcoding gene based on its widespread presence among different taxonomic groups (Hebert et al. 2004a; Hebert et al. 2004b; Saunders 2005; Ward et al. 2005). Moreover, nucleotide sequence polymorphisms of this approximately $500 \mathrm{bp}$ COI barcode region provide valuable information not only on species identification but also on population genetic diversity and structure (Goetze et al. 2016; Abbas et al. 2018; Choo et al. 2020). Several barcoding studies have also identified alternative genes that can be successfully used for molecular barcoding and may be more suitable to a specific taxonomic group. For example, the ribosomal genes 16 s and 18 s are generally used for the identification of prokaryotes (Stackebrandt 1994; Acina et al. 2004) and eukaryotes (Hadziavdic et al. 2014; Bradley et al. 2016), respectively; the nuclear ribosomal internal transcribed spacer 1 and 2 (ITS) for fungi (Scoch et al. 2012; Badotti et al. 2017); and two plastid genes, the maturase-coding gene (matK) and the large subunit of ribulose 1,5-bisphosphate carboxylase-coding gene (rbcL) for plants (CBOL 2009), among others.

In light of this, we wanted to evaluate the current status of DNA barcode availability for the NIS already detected in the Mediterranean through morphological surveys. To do so, we retrieved the most recent list of NIS published by Zenetos and Galanidi (2020) and we looked for the availability of COI barcodes and primers in reference libraries. If COI barcodes were not retrieved, we then searched for other barcoding genes. If no records were found in the reference libraries, this was then referred to as DNA barcode gap.

The aim of this research is to evaluate the current limitations in the application of molecular barcoding due to the barcode gap of Mediterranean NIS, and to investigate in 
depth the occurrence of COI gene barcode and primer pairs. Furthermore, we indicate which taxonomic groups may be underestimated by using molecular tools for the detection and biomonitoring of NIS in the Mediterranean Sea through environmental DNA.

\section{Materials and methods}

\section{Checklist of NIS occurring in the Mediterranean Sea}

We obtained an updated checklist of confirmed alien species occurring in the Mediterranean Sea using an inventory of NIS published by Zenetos and Galanidi at the start of 2020. In this inventory, a total of 666 marine NIS established in the Mediterranean Sea are divided into 10 high-ranked taxonomic groups, as defined by the authors (Zenetos and Galanidi 2020).

The names of the species were verified using the following platforms: EU-NOMEN (http://www.eu-nomen.eu), FishBase (https://www.fishbase.de), ALGAEBASE (https://www.algaebase.org), EASIN (https://easin.jrc.ec.europa.eu/easin) and WORMS (http://www.marinespecies.org) (Specchia et al. 2020). This resulted in a total number of 665 NIS because we excluded Chaetoceros bacteriastroides, an uncertain (unassessed) species on all the above-mentioned platforms. For each of the 665 NIS, we considered the currently accepted name and all of the synonyms and older names, to ensure that the species in question is really absent in the reference libraries.

\section{DNA barcode libraries interrogation and data analysis}

The 665 NIS official and alternative nomenclatures were manually entered in BOLD Systems and GenBank to search for a COI barcode. If a COI barcode was retrieved, we then looked into the availability of primer pairs and their use across different taxonomic groups. We also recorded other genes (5.8s, 12s, 16s, 18s, 28s, cytb, rbcL), when the COI barcode was not available, to correctly estimate the barcode gap. All the data was compiled in an Excel file available as Suppl. material 1: Table S1, which we used as a starting point to quantify the barcode gap as a percentage of species within each group.

\section{Results}

\section{COI barcode and primer gap in NIS occurring in the Mediterranean Sea}

In total, 665 NIS established in the Mediterranean Sea, belonging to 132 orders, were divided into 10 main taxonomic groups (Fish, Parasites, Phytobenthos, Ascidians, Bryozoa, Crustacea, Miscellanea, Mollusca, Polychaeta, and Zooplankton; Zenetos and Galanidi 2020), and their DNA barcoding gap in reference libraries was investigated. At the end of June 2021, 220 out of 665 NIS did not have any barcodes in reference 
libraries (BOLD Systems and GenBank), showing a barcoding gap of $33.18 \%$. Of the remaining 445 barcoded species, $14.16 \%$ did not have a COI barcode but still presented another gene barcode (Suppl. material 1: Table S1).

For the 382 species associated with a COI barcode in the DNA reference libraries, we further looked into the availability of primer pairs, finding that $45.30 \%$ do not have publicly available primer pairs. Moreover, of the 55 primer pairs found across different taxonomic groups, only 4 pairs were used in more than one phylum. They are LCO1490/HCO2198, LCO1490_t1/HCO2198_t1 and C_LepFolF/C_LepFolR found in Chordata, Arthropoda and Mollusca, and jgLCO1490/jgHCO2198 found in Arthropoda, Chordata, Mollusca, Bryozoa and Echinodermata. No universal primer pairs were identified.

\section{Barcode and primer pair gaps in taxonomic groups}

In the "Bryozoa" group, 30 NIS, divided into 2 orders, have been analysed. Among these, 23 species (76.67\%) were not associated with a DNA barcode (Fig. 1), representing the group with the largest gap. Six species present a COI barcode, while only one (Celleporella carolinensis) does not have any public record apart from a partial coding DNA sequence (cds) of the elongation factor 1 alpha. For this taxonomic group, only 1 primer pair (jgLCO1490/jgHCO2198) for COI gene amplification was identified and it is only used in two species of the same genus: Celleporaria aperta and Celleporaria brunea.

The second group with the most extensive barcode gap is represented by "Parasites", consisting of 25 NIS divided into 10 orders. In this group, 14 species (56\%) lack a barcode, $8(32 \%)$ have a COI barcode and $3(12 \%)$ have a different gene barcode (Fig. 1). The 3 species lacking COI have a record on GenBank of a coding sequence (cds) annotated as ribosomal subunit, which we identified through BlastN as 28s for Boninia neotethydis and Tetrancistrum polymorphum, and 18s for Thulinia microrchis.

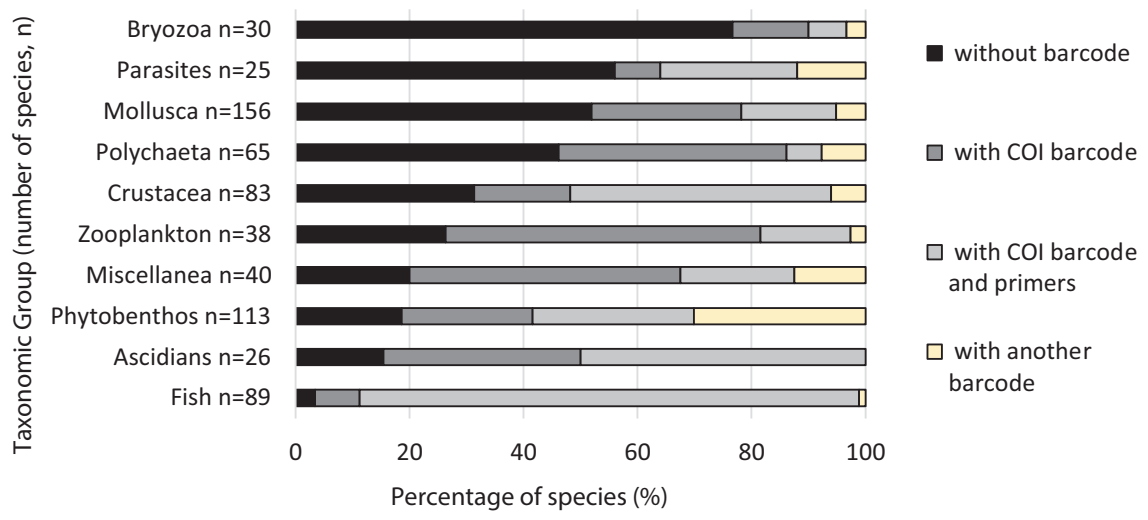

Figure I. DNA Barcode gap of Mediterranean NIS. Data are presented as a percentage of the total number of species in each group $(n)$. 
Like Bryozoa, Parasites display a substantial COI primer pair gap, having only 2 sets of primers available: HCO2198/LCO1490, only used in Heterosaccus dollfusi and jgHCO2198/jgLCO1490, only used in Livoneca redmanii.

The group "Mollusca" contains the highest number of NIS, amounting to 156 species divided into 28 orders. Among these, 81 species (51.92\%) are not associated with a DNA barcode, $67(42.95 \%)$ have a COI barcode, while $8(5.13 \%)$ have another barcode, mainly represented by $16 \mathrm{~s}, 18 \mathrm{~s}$ and $28 \mathrm{~s}$ (Fig. 1). For this taxonomic group, 13 different COI primer pairs have been identified. These primer pairs were tested in 26 species, leaving a COI primer pair gap in 41 species (26.81\%).

The group "Polychaeta" consists of 65 NIS, divided into 7 orders. Among these, 30 species $(46.15 \%)$ are not associated with a DNA barcode, $30(46.15 \%)$ have a COI barcode and $5(7.69 \%)$ have other barcodes, represented by the following genes: $5.8 \mathrm{~s}, 16 \mathrm{~s}, 18 \mathrm{~s}, 28 \mathrm{~s}$ and cytochrome b (cytb). This taxonomic group shows the largest COI primers pair gap, covering $86.67 \%$ of COI barcoded species. Only four primer pairs were found: jgLCO1490/jgHCO2198 used in Branchiomma bardi and Timarete punctata; polyLCO/polyHCO and C_VF1LFt1/C_VR1LRt1 both used in Pileolaria berkeleyana; and mlCOIintF/HCO2198 only used in Polydora cornuta.

The group "Crustacea" consists of 83 NIS, divided into 7 orders. Among these, 26 species $(31.33 \%)$ are not associated with a DNA barcode, 52 species $(62.65 \%)$ have a COI barcode and 5 species $(6.02 \%)$ have another barcode. Four out of these 5 species lacking COI present either 12s, 16s or both, while one (Thalamita poissonii), presents Thapmar 1.5 transposon as the only record. For this taxonomic group, 9 different primer pairs for COI amplification were found. These 9 primers were used in 38 species $(45.78 \%)$, while the remaining 14 species with COI sequence did not have a primer set, resulting in a COI primer pair gap of $16.87 \%$. The most used primer set is HCO2198/LCO1490, found in 26 out of 38 species (68\%).

The group "Zooplankton" consists of 38 NIS divided into 14 orders. Among these, $10(26.32 \%)$ are not associated with a DNA barcode, 27 (71.05\%) have a COI barcode and only one (Parvocalanus elegans) does not have COI but 28s, instead. This group is the one with the second largest COI primer pair gap, having 4 primer sets used only on 6 out of 26 COI barcoded species, giving a COI primer gap of $77.78 \%$.

The group "Miscellanea" consists of 40 NIS divided into 6 phyla and 21 orders. Among these, 8 species (20\%) are not associated with a DNA barcode, 27 (67.50\%) have a COI barcode and $5(12.50 \%)$ have either $16 \mathrm{~s}, 18 \mathrm{~s}$, or both. For this taxonomic group, eight primer pairs were found, but used only on 8 out of 27 COI barcoded species, leaving a primer pair gap of $70.37 \%$.

The group "Phytobenthos" is the second-largest NIS group, with 113 NIS divided into 27 orders. Among these, 21 species (18.58\%) are not associated with a DNA barcode, 58 species $(51.33 \%)$ have a COI barcode and 34 species $(30.09 \%)$ have another barcode. This is the group where an alternative barcode gene to COI has been used the most since COI is generally used for barcoding animal species. RbcL is the most represented gene for this group, covering 25 out of 34 species. For this taxonomic group, a total of 12 primer sets for COI amplification were found. These primers were used on 


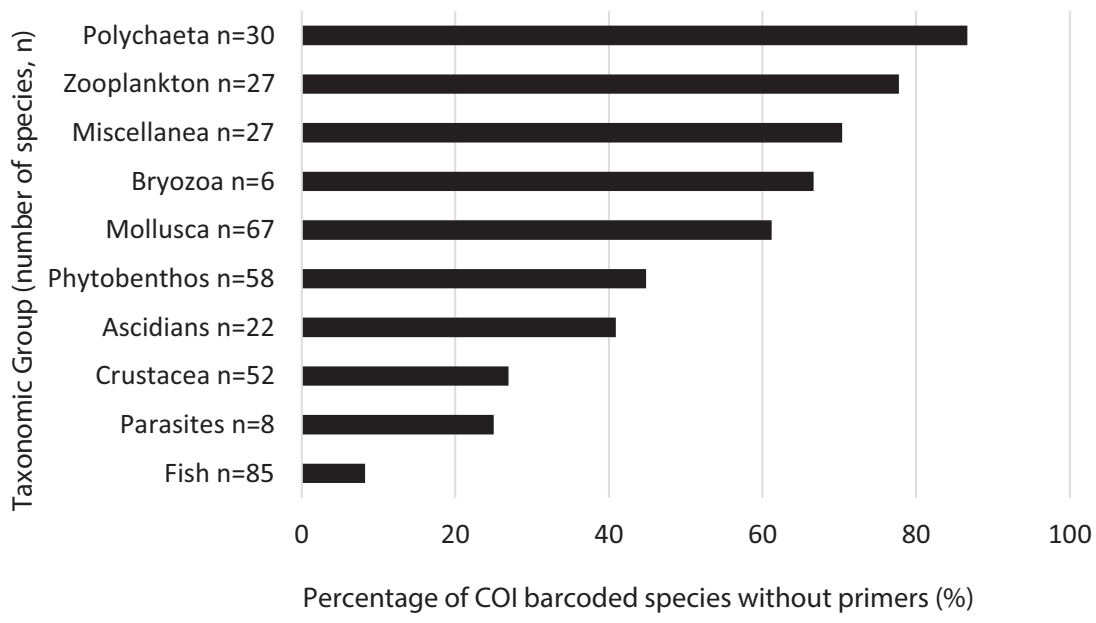

Figure 2. Primers not available in COI barcoded species. Data presented as a percentage of the total number of COI barcoded species

26 out of 58 species, leaving a COI primer pair gap of $44.83 \%$ (Fig. 2). The most used primer set is GWSFn/GWSRx, present in 17 out of 26 species $(65.38 \%)$.

The group "Ascidians" consists of 26 NIS divided into 3 orders. Among these, 4 species $(15.38 \%)$ are not associated with a DNA barcode and 22 species $(84.62 \%)$ have a COI barcode. No other barcoding genes were found. Five primer sets were identified, covering 13 out of 22 barcoded species, leaving a primer pair gap of $40.91 \%$. The most used primer sets are jgLCO1490/jgHCO2198 and Tun_Forward/Tun_reverse2, used in 6 and 7 species, respectively.

The group "Fish" consists of 89 NIS divided into 15 orders. Among these, only 3 (3.37\%) species are not associated with a barcode, 86 species (96.63\%) have a COI barcode and 1 (Caesio varilineata) does not have a COI barcode, but a 12s, instead (Fig. 1). For this taxonomic group, 19 different primer pairs for COI gene amplification have been identified. These 19 primers cover a total of 78 species, leaving only $8.24 \%$ of COI barcoded species without a primer set (Fig. 2). The most used primer sets are C_FishF1t1/C_FishR1t1 and VF2/VR1, found in 54 and 51 species respectively, 34 of which present both primers.

\section{Discussion}

The aim of this study was to quantify the extent of the DNA barcode gap for the NIS established in the Mediterranean Sea, as identified by Zenetos and Galanidi in 2020 and, in doing so, to direct the efforts of the scientific community towards specific taxonomic groups. The data show that 33\% of NIS do not have any record in public libraries, making it impossible to detect these species through DNA barcoding techniques. Bryozoa and Parasites are the ones with the largest gap relative to the total 
number of species in each group. However, Mollusca, which covers almost $25 \%$ of the total number of NIS, also needs attention having a barcode gap in $50 \%$ of the species, followed by Polychaeta with a gap of $41 \%$. On the other hand, Phytobenthos, Ascidians and especially Fish appear to be the groups that could be mostly identified through molecular techniques, having smaller barcode gaps of $18 \%, 14 \%$ and $3 \%$, respectively.

Our analysis highlighted the importance of analysing barcode gaps in reference libraries for the successful application of molecular tools (including eDNA and DNA metabarcoding) in biomonitoring assessments. Gap-analysis surveys focusing on DNA barcode presence in public repositories for different groups of species are recently gaining greater attention from the scientific community. Gap-analysis has already been applied on marine NIS (Duarte et al. 2021), on macrofauna of a region of the North Sea (Hestetun et al. 2020), on aquatic macroinvertebrates of South-East Italy (Specchia et al. 2020), on marine macroinvertebrates of the Atlantic Iberia (Leite et al. 2020), and on Ascidians and Cnidarians of the European Register of Marine Species (ERMS; Paz and Rinkevich 2021). However, to our knowledge, this is the first study that investigates the DNA barcode gap for NIS occurring in the Mediterranean Sea.

This study also confirms that COI is a useful genetic marker because it is broadly sequenced across different phyla, making it a good candidate gene for identifying species in an environmental sample. Nonetheless, relying only on one DNA fragment may lead to misidentification of pooled samples due to possible sequence similarity; this is why multigene approaches should be preferred in molecular biomonitoring studies (Zou et al. 2012; Chesters et al. 2015; Gangan et al. 2019). Phytobenthos could be the first group to apply this approach, having $30 \%$ of species already barcoded with rbcL but not with COI. This is probably explained by the fact that rbcL is a standard barcode for plants (CBOL 2009; Maloukh et al. 2017; Kang et al. 2017; Weigand et al. 2019), further proving the advantage of selecting not only universal barcodes but also relevant taxa-specific genes.

Moreover, the success of the eDNA metabarcoding is based on the availability of efficient primer sets for the amplification of several taxa in a given sample (Elbrecht et al. 2017; Tzafesta et al. 2021). However, only 26\% of NIS occurring in the Mediterranean Sea appear to have publicly available COI primers. Especially for animals, 147 species out of $324 \mathrm{COI}$ barcoded species (45.40\%) were lacking primer pairs, which highlights the need for further evaluation of primers or the design of new ones. In addition, no universal primer pair was identified, resulting in more laborious molecular identifications where an environmental sample needs to be amplified with several sets of taxa-specific or even species-specific primers to be correctly assessed.

For the above reasons, also the primer pair gap needs to be filled. In order to do so, both increasing the surveys regarding NIS occurring in the Mediterranean Sea and improving the barcoding studies at a global scale is essential, as well as biodiversity assessments (Zangaro et al. 2021). Although the content of the databases doubles approximately every 18 months (https://www.ncbi.nlm.nih.gov/genbank/ statistics/), probably many of the NIS established in the Mediterranean Sea come from underdeveloped regions, which cannot financially support molecular surveys. 
This is easily extrapolated by looking at the "Data Releases" page provided by BOLD Systems (https://www.boldsystems.org/index.php/datarelease). Because of that, we not only encourage collaboration of researchers in this sector, but we also stress the need for training and inclusion of researchers from developing countries, which represent the current and, probably, the future source of new and hard-to-detect NIS.

In conclusion, it is essential to underline that molecular techniques represent a great opportunity to improve the study on the occurrence and distribution of NIS. Hence, a specific gap needs to be filled by the scientific community to make molecular identification totally efficient and independent at a regional, national, and transnational level.

\section{Acknowledgements}

This research was supported by the ex-60\% fund from the Italian Ministry of University and Research, by Funding of Basic Research Activities (FFABR) from the Italian Ministry of University and Research (MUR) awarded to M. Pinna and V. Specchia, by the project "Dipartimenti di Eccellenza" awarded to DiSTeBA and by the ImPrEco project funded by Interreg ADRION Programme 2014-2020 awarded to M. Pinna that supported a grant for $\mathrm{F}$. Zangaro.

The authors are grateful to the anonymous reviewers for their useful comments and suggestions.

\section{References}

Abbas EM, Megahed ET, Hemeda SA, El-nahas A (2018) DNA barcoding and molecular population structure of two species from genus Diplodus based on COI gene in the Egyptian Mediterranean Sea. International Journal of Fisheries and Aquatic Studies 6: 1-8.

Acinas SG, Klepac-Ceraj V, Hunt DE, Pharino C, Ceraj I, Distel DL, Polz MF (2004) Finescale phylogenetic architecture of a complex bacterial community. Nature 430(6999): 551-554. https://doi.org/10.1038/nature02649

Badotti F, de Oliveira FS, Garcia CF, Martins Vaz AB, Camargos Fonseca PL, Alves Nahum L, Oliveira G, Góes-Neto A (2017) Effectiveness of ITS and sub-regions as DNA barcode markers for the identification of Basidiomycota (Fungi). BMC Microbiology 17: e42. https://doi.org/10.1186/s12866-017-0958-x

Bariche M, Al-Mabruk SA, Ateş MA, Büyük A, Crocetta F, Dritsas M, Edde D, Fortič A, Gavriil E, Gerovasileiou V, Gökoğlu M, Huseyinoglu F, Karachle P, Kleitou P, Terbiyik Kurt T, Langeneck J, Lardicci C, Lipej L, Pavloudi C, Pinna M, Rizgalla J, Rüştü Özen M, Sedano F, Taşkın E, Yildiz G, Zangaro F (2020) New Alien Mediterranean Biodiversity Records 2020. Mediterranean Marine Science 21(1): 129-145. https://doi.org/10.12681/mms.21987

Benson DA, Cavanaugh M, Clark K, Karsch-Mizrachi I, Lipman DJ, Ostell J, Sayers EW (2012) GenBank. Nucleic Acids Research 41(1): 36-42. https://doi.org/10.1093/nar/gks1195 
Bradley IM, Pinto AJ, Guest JS (2016) Design and Evaluation of Illumina MiSeq-Compatible, $18 \mathrm{~S}$ rRNA Gene-Specific Primers for Improved Characterization of Mixed Phototrophic Communities. Applied and Environmental Microbiology 82: 5878-5891. https://doi. org/10.1128/AEM.01630-16

Caesar RM, Sörensson M, Cognato AI (2006) Integrating DNA data and traditional taxonomy to streamline biodiversity assessment: an example from edaphic beetles in the Klamath ecoregion, California, USA. Diversity and Distributions 12(5): 483-489. https://doi. org/10.1111/j.1366-9516.2006.00237.x

Cagnacci F, Cardini A, Ciucci P, Ferrari N, Mortelliti A, Preatoni DG, Russo D, Scandura M, Wauters LA, Amori G (2012) Less is more: a researcher's survival guide in times of economic crisis. Hystrix, the Italian Journal of Mammalogy 23: 1-7.

CBOL Plant Working Group (2009) A DNA barcode for land plants. Proceedings of the National Academy of Sciences 106(31): 12794-12797. https://doi.org/10.1073/ pnas.0905845106

Chesters D, Zheng WM, Zhu CD (2015) A DNA Barcoding system integrating multigene sequence data. Methods in Ecology and Evolution 6: 930-937. https://doi. org/10.1111/2041-210X.12366

Choo LQ, Bal TMP, Goetze E, Peijnenburg KTCA (2020) Oceanic dispersal barriers in a holoplanktonic gastropod. Journal of Evolutionary Biology 34(1): 224-240. https://doi. org/10.1111/jeb.13735

Coll M, Piroddi C, Steenbeek J, Kaschner K, Lasram FBR, Aguzzi J, Ballesteros E, Bianchi CN, Corbera J, Dailianis T, Danovaro R, Estrada M, Froglia C, Galil BS, Gasol JM, Gertwagen R, Gil J, Guilhaumon F, Kesner-Reyes K, Kisitos MS, Koukouras A, Lampadariou N, Laxamana E, Lopez-Fe de la Cuadra CM, Lotze HK, Martin D, Mouillot D, Oro D, Raicevich S, Rius-Barille J, Saiz-Salinas JI, San Vicente C, Somot S, Templado J, Turon X, Vafidis D, Villanueva R, Voultsiadou E (2010) The biodiversity of the Mediterranean Sea: estimates, patterns, and threats. PLoS ONE 5(8): e11842. https://doi.org/10.1371/journal.pone.0011842

Collins RA, Wangensteen OS, O'Gorman EJ, Mariani S, Sims DW, Genner MJ (2018) Persistence of environmental DNA in marine systems. Communications Biology 1(1): 1-11. https://doi.org/10.1038/s42003-018-0192-6

Schoch CL, Seifert KA, Huhndorf S, Robert V, Spouge JL, Levesque CA, Chen W (2012) Fungal Barcoding Consortium Nuclear ribosomal internal transcribed spacer (ITS) region as a universal DNA barcode marker for Fungi. Proceedings of the National Academy of Sciences 109(16): 6241-6246. https://doi.org/10.1073/pnas.1117018109

Darling JA, Galil BS, Carvalho GR, Rius M, Viard F, Piraino S (2017) Recommendations for developing and applying genetic tools to assess and manage biological invasions in marine ecosystems. Marine Policy 85: 54-64. https://doi.org/10.1016/j.marpol.2017.08.014

Deiner K, Bik HM, Mächler E, Seymour M, Lacoursière Roussel A, Altermatt F, Creer S, Bista I, Lodge DM, de Vere N, Pfrender ME (2017) Environmental DNA metabarcoding: Transforming how we survey animal and plant communities. Molecular Ecology 26(21): 5872-5895. https://doi.org/10.1111/mec.14350

Di Sabatino A, Cristiano G, Pinna M, Lombardo P, Miccoli FP, Marini G, Vignini P, Cicolani B (2014) Structure, functional organization and biological traits of macroinvertebrate as- 
semblages from leaf-bags and benthic samples in a third-order stream of Central Apennines (Italy). Ecological Indicators 46: 84-91. https://doi.org/10.1016/j.ecolind.2014.06.005

Duarte S, Vieira PE, Lavrador AS, Costa FO (2021) Status and prospects of marine NIS detection and monitoring through (e) DNA metabarcoding. Science of the Total Environment, 751: 141729. https://doi.org/10.1016/j.scitotenv.2020.141729

Elbrecht V, Leese F (2017) Validation and development of COI metabarcoding primers for freshwater macroinvertebrate bioassessment. Frontiers in Environmental Science 5: e11. https://doi.org/10.3389/fenvs.2017.00011

Gangan SS, Pavan-Kumar A, K JA (2019) Multigene barcoding and phylogeny of selected Engraulidae species. DNA Mapping, Sequencing, and Analysis 30(3): 548-555. https://doi. org/10.1080/24701394.2019.1570175

Goetze EG, Hüdepohl PT, Chang C, Van Woudenberg L, Iacchei M, Peijnenburg KTCA (2016) Ecological dispersal barrier across the equatorial Atlantic in a migratory planktonic copepod. Progress in Oceanography 158: 203-212. https://doi.org/10.1016/j.pocean.2016.07.001

Hadziavdic K, Lekang K, Lanzen A, Jonassen I, Thompson EM, Troedsson C (2014) Characterization of the $18 \mathrm{~S}$ rRNA Gene for Designing Universal Eukaryote Specific Primers. PLoS ONE 9(2): e87624. https://doi.org/10.1371/journal.pone.0087624

Hebert PD, Ratnasingham S, De Waard JR (2003) Barcoding animal life: cytochrome c oxidase subunit 1 divergences among closely related species. Proceedings of the Royal Society of London. Series B: Biological Sciences 270(1): 96-99. https://doi.org/10.1098/rsbl.2003.0025

Hebert PD, Penton EH, Burns JM, Janzen DH, Hallwachs W (2004) Ten species in one: DNA barcoding reveals cryptic species in the neotropical skipper butterfly Astraptes fulgerator. Proceedings of the National Academy of Sciences 101(41): 14812-14817. https://doi. org/10.1073/pnas.0406166101

Hestetun JT, Bye-Ingebrigtsen E, Nilsson RH, Glover AG, Johansen PO, Dahlgren TG (2020) Significant taxon sampling gaps in DNA databases limit the operational use of marine macrofauna metabarcoding. Marine Biodiversity 50(5): 1-9. https://doi.org/10.1007/ s12526-020-01093-5

Ji Y, Ashton L, Pedley SM, Edwards DP, Tang Y, Nakamura A, Kitching R, Dolman PM, Woodcock P, Edwards FA, Larsen TH, Hsu WW, Benedick S, Harner C, Wilcove DS, Bruce C, Wang X, Levi T, Lott M, Emerson BC, Yu DW (2013) Reliable, verifiable and efficient monitoring of biodiversity via metabarcoding. Ecology Letters 16(10): 1245-1257. https://doi.org/10.1111/ele.12162

Kang Y, Deng Z, Zang R, Long W (2017) DNA barcoding analysis and phylogenetic relationships of tree species in tropical cloud forests. Scientific Reports 7(1): 1-9. https://doi. org/10.1038/s41598-017-13057-0

Katsanevakis S, Bogucarskis K, Gatto F, Vandekerkhove J, Deriu I, Cardoso AC (2012) Building the European Alien Species Information Network (EASIN): a novel approach for the exploration of distributed alien species data. BioInvasions Record 1(4): 235-245. https:// doi.org/10.3391/bir.2012.1.4.01

Katsanevakis S, Tempera F, Teixeira H (2016) Mapping the impact of alien species on marine ecosystems: the Mediterranean Sea case study. Diversity and Distributions 22(6): 694-707. https://doi.org/10.1111/ddi.12429 
Leese F, Altermatt F, Bouchez A, Ekrem T, Hering D, Meissner K, Mergen P, Pawlowski J, Piggott J, Rimet F, Steinke D, Taberlet P, Weigand A, Abarenkov K, Beja P, Bervoets L, Björnsdóttir S, Boets P, Boggero A, Bones A, Borja Á, Bruce K, Bursić V, Carlsson J, Čiampor F, Čiamporová-Zatovičová Z, Coissac E, Costa F, Costache M, Creer S, Csabai Z, Deiner K, DelValls Á, Drakare S, Duarte S, Eleršek T, Fazi S, Fišer C, Flot J, Fonseca V, Fontaneto D, Grabowski M, Graf W, Guðbrandsson J, Hellström M, Hershkovitz Y, Hollingsworth P, Japoshvili B, Jones J, Kahlert M, Kalamujic Stroil B, Kasapidis P, Kelly M, Kelly-Quinn M, Keskin E, Kõljalg U, Ljubešić Z, Maček I, Mächler E, Mahon A, Marečková M, Mejdandzic M, Mircheva G, Montagna M, Moritz C, Mulk V, Naumoski A, Navodaru I, Padisák J, Pálsson S, Panksep K, Penev L, Petrusek A, Pfannkuchen M, Primmer C, Rinkevich B, Rotter A, Schmidt-Kloiber A, Segurado P, Speksnijder A, Stoev P, Strand M, Šulčius S, Sundberg P, Traugott M, Tsigenopoulos C, Turon X, Valentini A, van der Hoorn B, Várbíró G, Vasquez Hadjilyra M, Viguri J, Vitonytė I, Vogler A, Vrålstad T, Wägele W, Wenne R, Winding A, Woodward G, Zegura B, Zimmermann J (2016). DNAqua-Net: Developing new genetic tools for bioassessment and monitoring of aquatic ecosystems in Europe. Research Ideas and Outcomes 2: e11321. https://doi.org/10.3897/ rio.2.e11321

Leite BR, Vieira PE, Teixeira MAL, Lobo-Arteaga J, Hollatz C, Borges LMS, Duarte S, Troncoso JS, Costa FO (2020) Gap-analysis and annotated reference library for supporting macroinvertebrate metabarcoding in Atlantic Iberia. Regional Studies in Marine Science, 36: 101307. https://doi.org/10.1016/j.rsma.2020.101307

Lejeusne C, Chevaldonné P, Pergent-Martini C, Boudouresque CF, Pérez T (2010) Climate change effects on a miniature ocean: the highly diverse, highly impacted Mediterranean Sea. Trends in Ecology \& Evolution 25(4): 250-260. https://doi.org/10.1016/j. tree.2009.10.009

Macher JN, Macher TH, Leese F (2017) Combining NCBI and BOLD databases for OTU assignment in metabarcoding and metagenomic datasets: The BOLD_NCBI_Merger. Metabarcoding and Metagenomics 1: e22262. https://doi.org/10.3897/mbmg.1.22262

Maloukh L, Kumarappan A, Jarrar M, Salehi J, El-Wakil H, Lakshmi TR (2017) Discriminatory power of rbcL barcode locus for authentication of some of United Arab Emirates (UAE) native plants. 3 Biotech 7(2): 1-7. https://doi.org/10.1007/s13205-017-0746-1

Mannino AM, Cicero F, Toccaceli M, Pinna M, Balistreri P (2019). Distribution of Caulerpa taxifolia var. distichophylla (Sonder) Verlaque, Huisman \& Procaccini in the Mediterranean Sea. Nature Conservation 37: 17-29. https://doi.org/10.3897/natureconservation.37.33079

Marrocco V, Sicuro A, Zangaro F, Pinna M (2018) First record of the protected species Pinna nobilis (Linnaeus, 1758) in the Aquatina Lagoon (NATURA 2000 site IT9150003, SouthEast Italian coastline). Nature Conservation 28: 51-59. https://doi.org/10.3897/natureconservation.28.26112

Marrocco V, Zangaro F, Sicuro A, Pinna M (2019) A scaling down mapping of Pinna nobilis (Linnaeus, 1758) through the combination of scientific literature, NATURA 2000, grey literature and citizen science data. Nature Conservation 33: 21-31. https://doi.org/10.3897/ natureconservation.33.30397 
Olenin S, Narščius A, Minchin D, David M, Galil B, Gollasch S, Marchini A, OcchipintiAmbrogi A, Ojaveer H, Zaiko A (2014) Making non-indigenous species information systems practical for management and useful for research: an aquatic perspective. Biological Conservation 173: 98-107. https://doi.org/10.1016/j.biocon.2013.07.040

Pawlowski J, Kelly-Quinn M, Altermatt F, Apothéloz-Perret-Gentil L, Beja P, Boggero A, Borja A, Bouchez A, Cordier T, Domaizon I, Feio MJ, Filipe AF, Fornaroli R, Graf W, Herder J, van der Hoorn B, Jones JI, Sagova-Mareckova M, Moritz C, Barquín J, Piggott JJ, Pinna M, Rimet F, Rinkevich B, Sousa-Santos C, Specchia V, Trobajo R, Vasselon V, Vitecek S, Zimmerman J, Weigand A, Leese F, Kahlert M (2018) The future of biotic indices in the ecogenomic era: Integrating (e)DNA metabarcoding in biological assessment of aquatic ecosystems. Science of the Total Environment 637-638: 1295-1310. https://doi. org/10.1016/j.scitotenv.2018.05.002

Paz G, Rinkevich B (2021) Gap analysis of DNA barcoding in ERMS reference libraries for ascidians and cnidarians. Environmental Sciences Europe 33(1): 1-8. https://doi. org/10.1186/s12302-020-00449-9

Pinna M, Janzen S, Franco A, Specchia V, Marini G (2017) Role of habitats and sampling techniques on macroinvertebrate descriptors and ecological indicators: An experiment in a protected Mediterranean lagoon. Ecological Indicators 83: 495-503. https://doi. org/10.1016/j.ecolind.2017.08.022

Pinna M, Saccomanno B, Marini G, Zangaro F, Kabayeva A, Khalaj M, Shaimardan L, D'Attis S, Tzafesta E, Specchia V (2021) Testing the Influence of Incomplete DNA Barcode Libraries on Ecological Status Assessment of Mediterranean Transitional Waters. Biology 10(11): 1092. https://doi.org/10.3390/biology10111092

Ponti M, Vadrucci MR, Orfanidis S, Pinna M (2009) Biotic indices for ecological status of transitional water ecosystems. Transitional Waters Bulletin 3(3): 32-90.

Ratnasingham S, Hebert PD (2007) BOLD: The Barcode of Life Data System (http://www. barcodinglife.org). Molecular Ecology Notes 7(3): 355-364. https://doi.org/10.1111/ j.1471-8286.2007.01678.x

Rees HC, Maddison BC, Middleditch DJ, Patmore JR, Gough KC (2014) The detection of aquatic animal species using environmental DNA-a review of eDNA as a survey tool in ecology. Journal of Applied Ecology 51(5): 1450-1459. https://doi.org/10.1111/13652664.12306

Saunders GW (2005) Applying DNA barcoding to red macroalgae: a preliminary appraisal holds promise for future applications. Philosophical transactions of the Royal Society B: Biological Sciences 360(1462): 1879-1888. https://doi.org/10.1098/rstb.2005.1719

Specchia V, Janzen S, Marini G, Pinna M (2017) The Potential Link between Mobile DNA and the invasiveness of the species. Journal of RNAi and Gene Silencing 13: 557-561.

Specchia V, Tzafesta E, Marini G, Scarcella S, D’Attis S, Pinna M (2020) Gap Analysis for DNA Barcode Reference Libraries for Aquatic Macroinvertebrate Species in the Apulia Region (Southeast of Italy). Journal of Marine Science and Engineering 8(7): 538. https:// doi.org/10.3390/jmse8070538

Stackebrandt E, Goebel BM (1994) Taxonomic note: a place for DNA-DNA reassociation and $16 \mathrm{~S}$ rRNA sequence analysis in the present species definition in bacteriology. Interna- 
tional Journal of Systematic and Evolutionary Microbiology 44(4): 846-849. https://doi. org/10.1099/00207713-44-4-846

Streftaris N, Zenetos A (2006) Alien Marine Species in the Mediterranean - the 100 'Worst Invasives' and their Impact. Mediterranean Marine Science 7(1): 87-118. https://doi. org/10.12681/mms. 180

Tiralongo F, Crocetta F, Riginella E, Lillo AO, Tondo E, Macali A, Mancini E, Russo F, Coco S, Paolillo G, Azzurro E (2020) Snapshot of rare, exotic and overlooked fish species in the Italian seas: A citizen science survey. Journal of Sea Research 164: 101930. https://doi. org/10.1016/j.seares.2020.101930

Tiralongo F, Lillo AO, Tibullo D, Tondo E, Martire CL, D’Agnese R, Macali A, Mancini E, Giovos I, Coco S, Azzurro E (2019) Monitoring uncommon and non-indigenous fishes in Italian waters: One year of results for the AlienFish project. Regional Studies in Marine Science 28: 100606. https://doi.org/10.1016/j.rsma.2019.100606

Tsiamis K, Azzurro E, Bariche M, Çinar ME, Crocetta F, De Clerck O, Galil B, Gómez F, Hoffman R, Jensen R, Kamburska L, Langeneck J, Langer RM, Levitt-Barmats Y, Lezzi M, Marchini A, Occhipinti-Ambrogi A, Ojaveer H, Piraino S, Shenkar N, Yankova M, Zenetos A, Žuljević A, Cristina Cardoso AC (2020) Prioritizing marine invasive alien species in the European Union through horizon scanning. Aquatic Conservation: Marine and Freshwater Ecosystems 30(4): 794-845. https://doi.org/10.1002/aqc.3267

Tzafesta E, Zangaro F, Specchia V, Pinna M (2021) An Overview of DNA-Based Applications for the Assessment of Benthic Macroinvertebrates Biodiversity in Mediterranean Aquatic Ecosystems. Diversity, in press. https://doi.org/10.3390/d13030112

Villèle X, Verlaque M (1995) Changes and Degradation in a Posidonia oceanica Bed Invaded by the Introduced Tropical Alga Caulerpa taxifolia in the North Western Mediterranean. Botanica Marina 38: 79-88. https://doi.org/10.1515/botm.1995.38.1-6.79

Ward RD, Zemlak TS, Innes BH, Last PR, Hebert PD (2005) DNA barcoding Australia’s fish species. Philosophical Transactions of the Royal Society B: Biological Sciences 360(1462): 1847-1857. https://doi.org/10.1098/rstb.2005.1716

Weigand H, Beermann AJ, Čiampor F, Costa FO, Csabai Z, Duarte S, Geiger MF, Grabowski M, Rimet F, Rulik B, Strand M, Szucsich N, Weigand AM, Willassen E, Wyler SA, Bouchez A, Borja A, Čiamporová-Zatovičová Z, Ferreira S, Dijkstra KDB, Eisendle U, Freyhof J, Gadawski P, Graf W, Haegerbaeumer A, van der Hoorn BB, Japoshvili B, Keresztes L, Keskin E, Leese F, Macher JN, Mamos T, Paz G, Pešić V, Pfannkuchen DM, Pfannkuchen MA, Price BW, Rinkevich B, Teixeira MAL, Várbíró G, Ekrem T (2019) DNA barcode reference libraries for the monitoring of aquatic biota in Europe: Gap-analysis and recommendations for future work. Science of the Total Environment 678: 499-524. https://doi. org/10.1016/j.scitotenv.2019.04.247

Zangaro F, Schifano V, Specchia V, Tzafesta E, Pinna M (2020) A new extralimital sighting of Monachus monachus (Hermann, 1779) in the Aquatina di Frigole NATURA 2000 site (IT9150003) beach (Salento peninsula, Apulia Region, Italy) after two decades: strategies for conservation are needed. Biodiversity Data Journal 8: e53950. https://doi.org/10.3897/ BDJ.8.e53950 
Zangaro F, Marini G, Specchia V, De Luca M, Visintin F, Bullo G, Richard J, Šalaja N, Rakar B, Lipej B, Kurtović Mrčelić J, Piasevoli G, Žuljević A, Zaimi N, Bejko D, Diku A, Karousou A, Hatziyanni E, Pinat M, Pinna M (2021) Building a transnational biodiversity geo-database of the protected areas in the Adriatic-Ionian Macro-Region: approaches and results from the IMPRECO Project. Biodiversity Data Journal 9: e67169. https://doi. org/10.3897/BDJ.9.e67169

Zenetos A, Galanidi M (2020) Mediterranean non-indigenous species at the start of the 2020s: recent changes. Marine Biodiversity Records 13(1): 1-17. https://doi.org/10.1186/ s41200-020-00191-4

Zou S, Li Q, Kong L (2012) Multigene barcoding and phylogeny of geographically widespread muricids (Gastropoda: Neogastropoda) along the coast of China. Marine Biotechnology 14(1): 21-34. https://doi.org/10.1007/s10126-011-9384-5

\section{Supplementary material I}

\section{Table S1}

Authors: Francesco Zangaro, Benedetta Saccomanno, Eftychia Tzafesta, Fabio Bozzeda, Valeria Specchia, Maurizio Pinna

Data type: excel file

Explanation note: COI PCR primer pairs.

Copyright notice: This dataset is made available under the Open Database License (http://opendatacommons.org/licenses/odbl/1.0/). The Open Database License $(\mathrm{ODbL})$ is a license agreement intended to allow users to freely share, modify, and use this Dataset while maintaining this same freedom for others, provided that the original source and author(s) are credited.

Link: https://doi.org/10.3897/neobiota.70.71862.suppl1 